\title{
RELATIONSHIP OF SLAUGHTER CARCASS TRAITS OF BALKAN GOAT KIDS
}

\author{
M. Žujović ${ }^{1}$ N. Memiši ${ }^{2}$, Z. Tomić ${ }^{1}$ N. Stanišić ${ }^{1}$ Z. Bijelić ${ }^{1}, N$. \\ Maksimovićc $^{1}$, G. Marinkov ${ }^{1}$
}

${ }^{1}$ Institute for Animal Husbandry, 11080 Belgrade, Republic of Serbia

${ }^{2}$ AD Mlekara - Subotica, 24000 Subotica, Republic of Serbia

Corresponding author: 52.zotom@gmail.com

Original scientific paper

\begin{abstract}
Objective of this study is to determine the correlation between slaughter traits of kids of Balkan goat breed. Research was carried out in underdeveloped region of Serbia, on altitude of approximately $850 \mathrm{~m}$. Semiintensive breeding system, of housing and care of goats was applied. Results of the study of slaughter properties are presented in this paper, also correlation between certain measures on carcass and carcass sides established in 96 kids of Domestic Balkan breed (gender ratio 50:50), slaughtered at the age of 90 days. Average dressing percentage of warm carcass with head and offal of investigated kid population was $58.19 \%$, whereas the value of the dressing percentage of cold carcass with head and offal was $45.19 \%$. Male kids had statistically significantly (at the level of $\mathrm{P}<0.05$ and $\mathrm{P}<0.01$ ) higher values of carcass mass and linear carcass and carcass side measures compared to female kids. Data on established correlation coefficients between slaughter traits of Domestic Balkan kids reflect presence of highly positive and statistically significant $(\mathrm{P}<0.001)$ correlative dependence. Linear regression coefficients of pre-slaughter body mass of kids, as well as coefficients of determination of linear regression (from 0.41 to 0.99) indicate that this trait has very significant effect on all dressing percentages and carcass and carcass side measures. Considering the expression of slaughter traits and correlation between them in kids of Balkan breed, obtained results should be used for formulating of future programs designed to improve the production of meat from autochthonous goat breeds.
\end{abstract}

Key words: kids, Domestic Balkan breed, correlation, slaughter results.

\section{Introduction}

World production of goat meat, even though four times less than the production of sheep meat, is very important especially in Africa, Asia and South America (Dubeuf et al., 2004). In the European Union production of goat meat is 
significantly less important and of lower volume, especially in countries where dairy goat breeds are reared, which means that the meat is secondary product (Shrestha and Fahmy, 2007). It is estimated that the goat meat in Europe makes approximately $10 \%$ of total quantity of sheep meat. Greece, Spain, Italy and France are major produces of this type of meat, since they produce two-third of total amount of goat meat produced in Europe (Dubeuf and Boiazoglu, 2009).

Indigenous breeds of small ruminants are important for subsistence and socioeconomic livelihoods of communities in developing countries (Kunene et al., 2009). In Serbia, no attention was directed to production of kid meat, since after the Second World War, in former Yugoslavia, rearing of goats was forbidden. From 1970 year, interest in rearing of goats has increased, so number of this species of domestic animals is constantly increasing and on the market kids for slaughter predominantly lighter $(8-12 \mathrm{~kg}$ ), rarely heavier (above $15 \mathrm{~kg}$ ) can be found. It is estimated that presently 200.000 goats are reared on the territory of Republic of Serbia (Žujović et al., 2008).

Even though the main product obtained from goats on the territory of Serbia is milk, production of meat should not be neglected. It is important to use in the right way high biological fertility potential of goats (Memiši et al., 2010). Goats are known as the most fertile ruminants, which many breeders have used for increase of production of kid meat by forcing the fertility of goats and creating breeds which give annually in one kidding in average 2 to 3 kids (Devendra, 2007). This ability of goats can be used in two-time kidding of goats, where production of kid meat is more profitable than production of milk, and where for any reason there is lack of interest in goat milk production, or there are no conditions for the organized marketing of large quantities of milk, or for its processing (Memiši and Bauman, 2007). Goat population in hilly-mountainous region of Serbia is mainly domestic Balkan goat of red to sorrel colour with black, white and spotted varieties (Žujović et al., 2008). This is a dairy breed, for which it is characteristic that the front part of the carcass is less developed than the rear part, they are of rough constitution, resistant to diseases and with very modest requirements in regard to nutrition and care.

Given that the studies of the slaughter and carcass traits of Balkan goat in Serbia have been very rare, there is lack of literature references and data on these kid properties (Žujović et al., 2006). Objective of this study is to present main slaughter traits of Balkan breed kids at the age of 90 days, as well as to determine the correlation between certain slaughter traits of Balkan breed kids in order to use obtained results in programs for improvement of production of meat from goats. 


\section{Materials and Methods}

Research was carried out in herds of Balkan goats kept on individual farms. In 96 kids of Domestic Balkan breed (gender ratio 50:50), the production of meat was studied in a semi-intensive rearing system.

Goat farms of private breeders are located at the altitude of $850 \mathrm{~m}$ which is sub-alpine climate with not so severe winters and relatively warm summers, with predominant stable and clear weather. According to seasonal preciptiation distribution, springs has the most rain $-27 \%$ of total precipitation, followed by autumn with $25 \%$, whereas summer and winter have same amount of precipitation $-24 \%$ each of annual sum. Mountain pastures of the studied area are characterized by short vegetation period of 200 to 220 days in a year, temperature osciallations, strong impact of atmosphere factors and uneven yields. Pasture and meadow vegetation existing at this latitude consists mainly of grasses such as: Anthoxantum odoratum, Bromus tectorum, Festuca ovina, Stachys recta, Potentila argenta, Orchis ustulata, Lotus corniculatu, etc.

The system of management in the local areas was semi-intensive. The animals during day are kept on pasture, and in the night they are kept in stables. Goat stables for housing of goats are mainly built of combined hard material (stone and wood) and covered with metal roof. Nutrition of goats in summer is based on grazing or green mass, and in winter on hay of medium or poor quality. Additional nutrition using concentrated feeds is manly based on cracked grains (wheat and barley) and bran, and the silage is not used in goat nutrition.

Nutrition of kids during suckling period of 90 days consisted of mother's milk. Kids remained with goats until weaning, and during this period they were housed in special box (made of mobile planks) and they were provided with forage mixture and meadow hey in order to get them used to roughage. Concentrated part of the diet consisted of cracked corn and wheat bran supplemented with livestock salt. Meadow hey used in nutrition of kids was from the second cut and originated from meadows located at the altitude of approximatly $850 \mathrm{~m}$. In the yield of grasses, i.e. hey, 2/3 were following grasses Agrostis vulgaris L., Festuca rubra L., Alopecurus partenisis L., Dactylis glomerata L., Bromus vulgars L., Bromus mollis L. Etc. Leguminous plants were present in very low percentage $(2 \%$ usually Trifolium alpestre L., Trifolium montanum L., Trifolium repens L., Lotus corniculatus L. etc.). Nutrition of kids was ad libitum, food was administered twice per day, in the morning and evening hours. Water was also ad libitum.

Kids were slaughtered at the age of 90 days. Subsequent to slaughtering and primary carcass treatment, weight of warm carcass with head and offal was registered. After cooling period of $24 \mathrm{~h}$ at the temperature of 0 to $+4^{\circ} \mathrm{C}$, weight of cold carcass with head and offal was determined, as well as without head and offal. Following linear carcass measures (length and width of the carcass) were taken 
after cooling: Calcaneum - Ischium (pin bone), tail head - neck, Articulation genus - Articulation humeri, tail head - Atlas, Width of both legs/thighs, Breast width, Scapula width and Breast depth. After cutting of the carcasses into carcass sides, the following measures were taken on the left carcass side: Pubis - Talus ankle/joint, Pubis - I rib, Pubis - Atlas, Pubis - Articulatio genus.

Statistical analysis of data was done by application of several program procedures (Proc MEANS, Proc CORR, Proc REG) of the statistical program package SAS (SAS 9.1.3, 2007). In the regression analysis, independent variable value was pre-slaughter body weight of kids, whereas slaughter and carcass traits were dependent variables.

\section{Results and Discussion}

Descriptive statistical indicators of slaughter traits and carcass measurments of Balkan breed kids as presented in Table 1. Higher values of dressing percentage/meat yield were established in male kids, as well as linear measures on carcass and carcass sides, compared to female kids. However, statistically significant differences at the level of $p<0.05$ were determined in mass of cold and warm carcass with head and offal, as well as mass of cold carcass without offal, whereas statistically significant differences at the level $p<0.01$ were determined for certain values of carcass linear measures (breast width and scapula width) and measured lengths on carcass sides (Pubis - Talus ankle/joint). 
Table 1. Slaughter traits and carcass measuerments of Balkan breed kids

\begin{tabular}{|c|c|c|c|c|c|c|c|}
\hline Traits & Sex & $\mathrm{N}$ & Mean & Min & Max & $\mathrm{SD}^{1}$ & $\mathrm{CV}^{2}$ \\
\hline \multirow{3}{*}{ Pre-slaughter body weight (kg) } & Total & 96 & 13.31 & 10.63 & 16.08 & 1.05 & 7.93 \\
\hline & $\mathrm{M}$ & 48 & 13.51 & 10.86 & 16.08 & 1.11 & 8.24 \\
\hline & $\mathrm{F}$ & 48 & 13.12 & 10.63 & 15.67 & 0.97 & 7.37 \\
\hline \multirow{3}{*}{$\begin{array}{l}\text { Weight of warm carcass with head } \\
\text { and offal }(\mathrm{kg})\end{array}$} & Total & 96 & 7.74 & 6.32 & 9.07 & 0.51 & 6.63 \\
\hline & M & 48 & $7.86^{*}$ & 6.32 & 9.07 & 0.55 & 6.95 \\
\hline & $\mathrm{F}$ & 48 & 7.62 & 6.39 & 8.80 & 0.45 & 5.92 \\
\hline \multirow{3}{*}{$\begin{array}{l}\mathrm{DP}^{3} \text { of warm carcass with head and } \\
\text { offal }(\%)\end{array}$} & Total & 96 & 58.19 & 56.07 & 61.12 & 1.33 & 2.28 \\
\hline & M & 48 & 58.27 & 56.07 & 61.02 & 1.33 & 2.28 \\
\hline & $\mathrm{F}$ & 48 & 58.13 & 56.10 & 61.12 & 1.34 & 2.30 \\
\hline \multirow{3}{*}{$\begin{array}{l}\text { Weight of cold carcass with head and } \\
\text { offal }(\mathrm{kg})\end{array}$} & Total & 96 & 7.41 & 6.05 & 8.72 & 0.50 & 6.73 \\
\hline & M & 48 & $7.53^{*}$ & 6.05 & 8.72 & 0.53 & 7.04 \\
\hline & $\mathrm{F}$ & 48 & 7.29 & 6.12 & 8.46 & 0.44 & 6.03 \\
\hline \multirow{3}{*}{$\begin{array}{l}\text { DP of cold carcass with head and } \\
\text { offal }(\%)\end{array}$} & Total & 96 & 55.75 & 53.76 & 58.44 & 1.23 & 2.21 \\
\hline & M & 48 & 55.83 & 53.79 & 58.44 & 1.24 & 2.22 \\
\hline & $\mathrm{F}$ & 48 & 55.66 & 53.76 & 58.34 & 1.23 & 2.22 \\
\hline \multirow{3}{*}{$\begin{array}{l}\text { Weight of cold carcass without offal } \\
(\mathrm{kg})\end{array}$} & Total & 96 & 6.01 & 4.91 & 6.96 & 0.37 & 6.09 \\
\hline & M & 48 & $6.10^{*}$ & 4.91 & 6.96 & 0.39 & 6.42 \\
\hline & $\mathrm{F}$ & 48 & 5.92 & 5.01 & 6.76 & 0.32 & 5.38 \\
\hline \multirow{3}{*}{ DP of cold carcass without offal $(\%)$} & Total & 96 & 45.19 & 42.74 & 48.22 & 1.31 & 2.89 \\
\hline & M & 48 & 45.24 & 43.14 & 48.22 & 1.36 & 3.00 \\
\hline & $\mathrm{F}$ & 48 & 45.15 & 42.74 & 47.62 & 1.27 & 2.81 \\
\hline \multirow{3}{*}{$\begin{array}{l}\text { Calcaneum - Ischium (pin bone) } \\
(\mathrm{cm})\end{array}$} & Total & 96 & 24.38 & 21.50 & 27.50 & 1.28 & 5.25 \\
\hline & M & 48 & 24.63 & 22.00 & 27.50 & 1.29 & 5.26 \\
\hline & $\mathrm{F}$ & 48 & 24.14 & 21.50 & 26.50 & 1.23 & 5.11 \\
\hline \multirow{3}{*}{ Tail head - neck $(\mathrm{cm})$} & Total & 96 & 47.83 & 44.00 & 52.00 & 1.71 & 3.58 \\
\hline & $\mathrm{M}$ & 48 & 48.15 & 44.00 & 52.00 & 1.82 & 3.78 \\
\hline & $\mathrm{F}$ & 48 & 47.51 & 44.50 & 51.50 & 1.55 & 3.27 \\
\hline \multirow{3}{*}{$\begin{array}{l}\text { Articulatio genus - Articulatio humeri } \\
(\mathrm{cm})\end{array}$} & Total & 96 & 57.92 & 55.00 & 62.50 & 1.48 & 2.56 \\
\hline & M & 48 & 58.21 & 56.00 & 62.50 & 1.52 & 2.60 \\
\hline & $\mathrm{F}$ & 48 & 57.63 & 55.00 & 62.00 & 1.41 & 2.44 \\
\hline \multirow{3}{*}{ Tail head - Atlas $(\mathrm{cm})$} & Total & 96 & 65.00 & 61.50 & 70.00 & 1.95 & 2.99 \\
\hline & $\mathrm{M}$ & 48 & $65.40^{*}$ & 61.50 & 70.00 & 2.06 & 3.15 \\
\hline & $\mathrm{F}$ & 48 & 64.60 & 61.50 & 69.00 & 1.76 & 2.72 \\
\hline \multirow{3}{*}{ Width of both legs/thighs $(\mathrm{cm})$} & Total & 96 & 12.38 & 10.50 & 14.50 & 0.76 & 6.14 \\
\hline & $\mathrm{M}$ & 48 & $12.56^{*}$ & 11.00 & 14.50 & 0.73 & 5.84 \\
\hline & $\mathrm{F}$ & 48 & 12.20 & 10.50 & 14.00 & 0.75 & 6.14 \\
\hline \multirow{3}{*}{ Breast width $(\mathrm{cm})$} & Total & 96 & 12.47 & 10.50 & 14.50 & 0.71 & 5.74 \\
\hline & $\mathrm{M}$ & 48 & $12.67^{* *}$ & 11.00 & 14.50 & 0.68 & 5.36 \\
\hline & $\mathrm{F}$ & 48 & 12.28 & 10.50 & 13.50 & 0.71 & 5.75 \\
\hline \multirow{3}{*}{ Scapula width $(\mathrm{cm})$} & Total & 96 & 12.52 & 11.00 & 14.50 & 0.62 & 4.98 \\
\hline & $\mathrm{M}$ & 48 & $12.69^{* *}$ & 11.50 & 14.50 & 0.60 & 4.71 \\
\hline & $\mathrm{F}$ & 48 & 12.35 & 11.00 & 13.50 & 0.61 & 4.94 \\
\hline \multirow{3}{*}{ Breast depth $(\mathrm{cm})$} & Total & 96 & 21.54 & 18.00 & 24.50 & 1.32 & 6.12 \\
\hline & $\mathrm{M}$ & 48 & 21.75 & 18.00 & 24.50 & 1.31 & 6.04 \\
\hline & $\mathrm{F}$ & 48 & 21.32 & 18.00 & 24.00 & 1.30 & 6.11 \\
\hline \multirow{3}{*}{ Pubis - Talus ankle/joint $(\mathrm{cm})$} & Total & 96 & 27.79 & 25.50 & 31.50 & 1.18 & 4.24 \\
\hline & M & 48 & $28.09^{* *}$ & 26.00 & 31.50 & 1.18 & 4.20 \\
\hline & $\mathrm{F}$ & 48 & 27.48 & 25.50 & 30.50 & 1.11 & 4.02 \\
\hline & Total & 96 & 53.02 & 50.00 & 56.00 & 1.29 & 2.43 \\
\hline Pubis - I rib (cm) & $\mathrm{M}$ & 48 & $53.31^{*}$ & 51.00 & 56.00 & 1.19 & 2.24 \\
\hline & $\mathrm{F}$ & 48 & 52.73 & 50.00 & 55.50 & 1.33 & 2.52 \\
\hline & Total & 96 & 63.98 & 61.00 & 68.00 & 1.47 & 2.30 \\
\hline Pubis - Atlas $(\mathrm{cm})$ & $\mathrm{M}$ & 48 & $64.28^{*}$ & 61.00 & 68.00 & 1.60 & 2.49 \\
\hline & $\mathrm{F}$ & 48 & 63.68 & 61.00 & 67.00 & 1.29 & 2.02 \\
\hline & Total & 96 & 16.47 & 14.00 & 18.00 & 0.97 & 5.89 \\
\hline Pubis - Articulatio genus $(\mathrm{cm})$ & $\mathrm{M}$ & 48 & 16.65 & 15.00 & 18.00 & 0.96 & 5.78 \\
\hline & $\mathrm{F}$ & 48 & 16.29 & 14.00 & 18.00 & 0.96 & 5.87 \\
\hline
\end{tabular}

p-level: * $\mathrm{P}<0.05,{ }^{* *} \mathrm{P}<0.01$; M-Male; F-Female; ${ }^{1}$ - Standard deviation; ${ }^{2}$ - Coefficient of variation;

3 - Dressing percentage 
Coefficients of determination (Table 2) indicate that the percentage of variability of studied dressing percentage values as well as determined measures on carcass and carcass sides, was in range from 0.41 to 0.99 , which confirms the effect of pre-slaughter body weight of kids on observed slaughter characteristics.

Table 2. Coefficients and significance of linear regression of pre-slaughter body weight on major slaughter traits of Balkan breed kids

\begin{tabular}{|l|c|c|c|c|}
\hline Traits & $\mathrm{R}^{2}$ & $F(1,94)$ & $\mathrm{Rc}^{1}$ & $P^{*}$ \\
\hline Weight of warm carcass with head and offal $(\mathrm{kg})$ & 0.99 & 1357.7 & 0.469906 & 0.00 \\
\hline DP $^{2}$ of warm carcass with head and offal (\%) & 0.44 & 73.768 & -0.83383 & 0.00 \\
\hline Weight of cold carcass with head and offal (kg) & 0.94 & 1406.1 & 0.458049 & 0.00 \\
\hline DP of cold carcass with head and offal (\%) & 0.41 & 64.910 & -0.74658 & 0.00 \\
\hline Weight of cold carcass without offal (kg) & 0.89 & 785.81 & 0.327852 & 0.00 \\
\hline DP of cold carcass without offal (\%) & 0.51 & 97.332 & -0.88297 & 0.00 \\
\hline Calcaneum - Ischium (pin bone) (cm) & 0.78 & 345.40 & 1.07615 & 0.00 \\
\hline Tail head - neck (cm) & 0.80 & 388.85 & 1.45706 & 0.00 \\
\hline Articulatio genus - Articulatio humeri (cm) & 0.76 & 299.57 & 1.22719 & 0.00 \\
\hline Tail head - Atlas (cm) & 0.81 & 399.53 & 1.65968 & 0.00 \\
\hline Width of both legs/thighs (cm) & 0.74 & 277.64 & 0.62246 & 0.00 \\
\hline Breast width (cm) & 0.70 & 224.88 & 0.569660 & 0.00 \\
\hline Scapula width (cm) & 0.61 & 148.24 & 0.462351 & 0.00 \\
\hline Breast depth (cm) & 0.69 & 212.57 & 1.040269 & 0.00 \\
\hline Pubis - Talus ankle/joint (cm) & 0.83 & 461.04 & 1.01751 & 0.00 \\
\hline Pubis - I rib (cm) & 0.73 & 256.80 & 1.04543 & 0.00 \\
\hline Pubis - Atlas (cm) & 0.81 & 412.19 & 1.26056 & 0.00 \\
\hline Pubis - Articulatio genus (cm) & 0.75 & 287.00 & 0.797844 & 0.00 \\
\hline
\end{tabular}

* - level of significance $\mathrm{P}<0.001 ;{ }^{1}$ - Regression coefficient; ${ }^{2}$ - Dressing precentage

Data obtained on slaughter traits of Domestic Balkan goat can be compared to results obtained by other authors, but there are certain discrepancies considering the diversity in breeds, body masses and ages of kids included in trials. Results for dressing percentage obtained in this research are higher or same as those stated by Žujović et al. (2009) for kids of Domestic Balkan breed on farms of individual producers in Serbia. Similar values for dressing percentage of the warm carcass in two groups of kids of Serbian White breed, slaughtered at the age of 70 days, are reported by Žujović et al. (2008). In lighter kids of average pre-slaughter body mass of $12.654 \mathrm{~kg}$ (from 8.8 to $15.0 \mathrm{~kg}$ ) and medium heavy kids of average body mass of $17.61 \mathrm{~kg}$ (from 15.1 to $20.0 \mathrm{~kg}$ ), established the dressing percentage of $57.21 \%$ and $55.01 \%$, respectively. Obtained results are in favour of the conclusion that with the decrease of pre-slaughter body mass higher values of 
dressing percentage are realized (Bolacali and Kucuk, 2008). Lower values for dressing percentage of warm carcass $(49.71,49.27$ and $48.78 \%$ ) and hot carcass weights $(6.78,7.61$ and $7.02 \mathrm{~kg}$ ) in kids Hair Goat, Saanen x Hair Goat (F1 and B1) slaughtered at the age of 4 months, are reported by Yilmaz et al. (2009) and Arguello et al. (2007) for dressing percentages in kids of different genotypes.

In this study higher values of dressing precentage/meat yield and of certain carcass linear measures were determined in male kids compared to females, which is in complete agreement with results obtained by other authors (Peña et al., 2007; Domingo et al., 2008). In addition, expression of observed traits greatly depends on goat genotype as well as management of animal nutrition and care.

In the research carried out by Gruszetski et al. (1997) on 35 kids of White improved breed reared in Poland, slaughtered with body mass of $20 \mathrm{~kg}$, lower value of the dressing percentage of cold carcass was established (43.79\%). The authors established in studied population of animals at the age of 2 months body mass of $11.83 \mathrm{~kg}$ which was lower compared to body mass determined in present research, which was $13.83 \mathrm{~kg}$ at the age of 90 days, proving that kids of Balkan breed have lower production potential.

Obtained results for mass of warm and cold carcass with and without head and offal, as well as value of dressing percentage of warm carcass of Balkan goat, are also similar to those established by Becerril-Herrera et al. (2006), in kids of Mexican Creole goat breed (59.27\%). The authors state statistically significant correlation of 0.83 and 0.76 for certain slaughter traits such as mass of warm and cold carcass in elation to pre-slaughter body mass, which was slightly lower compared to results obtained in this research (0.97 and 0.95). Marichal et al. (2003), report similar values of dressing percentage in kids reared on Canary islands.

Values of the dressing percentage of cold carcass without head and offal obtained in present study are similar to results of the research reported by Daskiran et al. (2006) in their study of slaughter traits of 15 male kids of Norduz goat breed reared in Turkey in intensive (41.49\%) and grazing system (44.63\%). Bolacali and Kucuk (2008), in their study of fattening traits and quality of meat obtained from two goat genotypes (Angora x Moher coloured and Moher coloured) obtained similar values of carcass dressing percentage ( 44.3 and $45.5 \%$ ).

Based on data obtained in this research statistically significant correlation $(\mathrm{P}<0.001)$ was established between all observed slaughter traits in kids slaughtered at the age of 90 days (Table 3 ). 


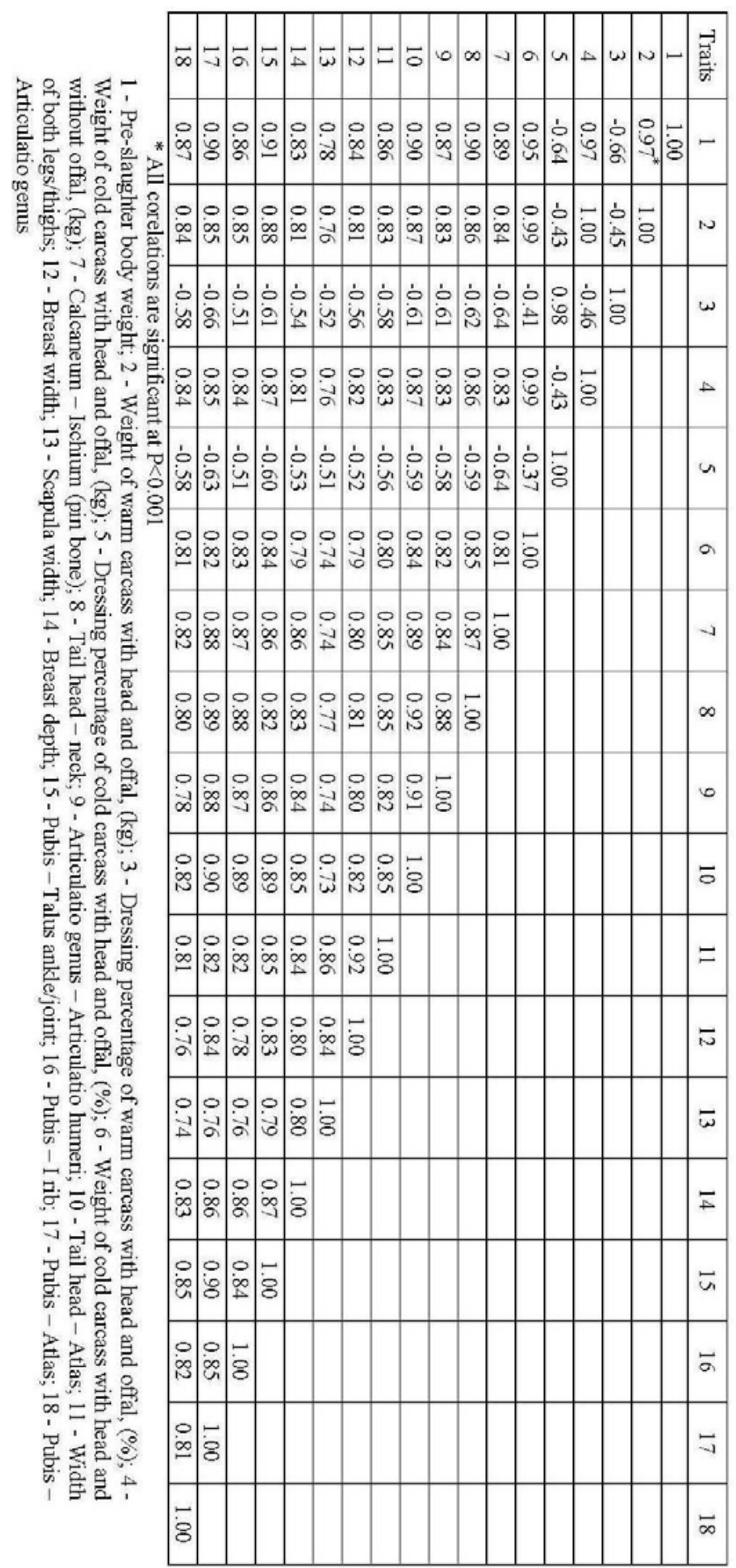


Results obtained for certain slaughter traits (mass of warm carcass and dressing percentage/meat yield) established in kids of Domestic Balkan goat breed, were at the level of those presented by Ekiz et al. (2010) for kids of Turkish Saanen and Maltese breeds of average pre-slaughter wight of 13.31 and $14.48 \mathrm{~kg}$ with mass of warm carcass of 7.22 and $7.68 \mathrm{~kg}$ and dressing percentage of 54.26 and $53.01 \%$. In the analysis of the effect of various rearing systems (stable and pasture) on production of meat in autochthonous goat population Cilentana, Cutrignelli et al. (2005), in 12 kids slaughtered at the age of 60 days and body mass from 11.78 to $12.41 \mathrm{~kg}$, established lower carcass measures. In the research of Fajemilehin and Salako (2008) on 244 West African Dwarf goats, average body length of female and male goats, in age group of 0-1 year, was $37.07 \mathrm{~cm}$ and 28,98 $\mathrm{cm}$ respectively. Also, authorst state determination coefficients $(0.41$ to 0.78$)$ for traits of body development for West African Dwarf goats in correlation with slaughter traits, similar to those obtained in present study (0.41 to 0.99$)$.

Higher values of certain carcass measures (Polish White improved goat and its crosses with Boer goat breed), slaughtered with body mass of $20 \mathrm{~kg}$, are reported by Stanisz et al. (2009). In study by Bonvillan et al. (2010) in kids of Criollo Cordobes breed slaughtered at the age of 90 days and body mass of 9.5 to $11 \mathrm{~kg}$, statistically significant correlation was determined $(\mathrm{p}<0.05)$ for some slaughter traits which are somewhat lower compared to results obtained in the present study. Lower values of established correlation coefficients for slaughter traits are reported also by Santos et al. (2007) in kids from goats of various genotypes.

\section{Conclusion}

Expression and correlation between slaughter traits of kids of Balkan goat breed are within expected biological frames for this group of goats and are similar to results obtained for other local or autochthonous goat breeds reared in other regions of Europe or world. The most significant results show that pre-slaughter body mass of Balkan breed kids at the age of 90 days in average was $13.3 \mathrm{~kg}$, average dressing percentage/meat yield of warm carcass with head and offal approx. $58,2 \%$, whereas the average dressing percentage/meat yield of cold carcass without head and offal was approx. 45,2\%. Established correlationbetween studied slaughter traits in kids of Domestic Balkan goat breed confirm the presence of positive and statistically highly significant $(\mathrm{P}<0,001)$ correlation. On the other hand, linear regression coefficients of the effect of pre-slaughter body mass of kids on slaughter traits, as well as coefficients of determination of linear regression (from 0.41 to 0.99 ), indicate that this trait had significant influence on all dressing percentages/meat yields and carcass and carcass side measures. Considering the expression of slaughter traits and correlation between them in kids of Balkan breed, 
obtained results should be used for formulating of future programs designed to improve the production of meat from autochthonous goat breeds.

\title{
Acknowledgements
}

Research was financed by the Ministry of Education and Science, Republic of Serbia, project TR 31053.

\section{Povezanost klaničnih osobina jaradi balkanske rase koza}

\author{
M. Žujović, N. Memiši, Z. Tomić, N. Stanišić, Z. Bijelić, N. Maksimović, G. \\ Marinkov
}

\section{Rezime}

Cilj ovog rada je da se utvrdi povezanost (korelacija) između klaničnih parametara jarića balkankse rase koza. Istraživanja su izvedena u nerazvijenom području R Srbije na nadmorskoj visini od oko $850 \mathrm{~m}$. Primenjen je poluintenzivan sistem odgoja, smeštaj i nege koza. U radu su prikazani rezultati ispitivanja klaničnih karakteristika i utvrđena korelaciona povezanost osobina pojedinih mera na trupu i polutkama, kod 96 jaradi domaće balkanske koze (sa odnosom polova 50:50) koja su zaklana u uzrastu od 90 dana. Prosečan randman toplog trupa sa glavom i iznutricama kod jaradi ispitivane populacije iznosio je $58,19 \%$ dok je vrednost randmana hladnog trupa sa glavom bez iznutrica bila 45,19\%. Muška jarad su imala statistički značajno teža i imala su veće linearne mere trupa (na nivou $\mathrm{P}<0,05$ i $\mathrm{P}<0,01$ ) u poređenju sa ženskim. Podaci o koeficijentima korelacije izmedju ispitivanih klaničnih karakteristika jaradi domaće balkanske koze, odražavaju postojanje visoko pozitivne i statistički značajne $(\mathrm{P}<0,001)$, korelativne zavisnosti. Linearni regresioni koeficijenti telesne mase jaradi pred klanje, kao i koeficijenti determinacije linearne regresije (od 0.41 do 0.99 ), ukazuju na to da ova osobina veoma značajno utiče na sve randmane i mere na trupu i polutkama. Imajući u vidu ispoljenost i povezanost ispitivanih klaničnih karakteristika kod jaradi balkanske rase koza, dobijeni rezultati treba da se iskoriste $u$ formulisanju budućih programa unapređenja proizvodnje mesa kod autohtnonih rasa koza. 


\section{References}

ARGÜEllo A., CASTRO N., CAPOTE J., SOlOMON M.B. (2007): The influence of artificial rearing and live weight at slaughter on kid carcass characteristics. Journal of Animal and Veterinary Advances, 6, 1, 20-25.

BECERRIL-HERRERA M., GUZMAN-PINA O., ALONSO-SPILSBURY M., DORSEZ-SAN VICENTE E.V., LEMUS-FLORES C., FLORE-PEINADO S., RAMIREZ-NECOECHEA R., MOTA-ROJAS D. (2006): Morphometry, carcass yield and traits of Mexican Creole goat kids slaughtered and packed in a federal inspection plant. J. Biol. Sci., 6, 604-609.

BOLACALI M., KUCUK M. (2008): Fattening performance, Slaughter and carcass characteristics of male kids of coloured Mohair goats and Angora goats $\mathrm{x}$ Coloured Mohair goats cross-breed F1. J. Anim. Vet. Adv., 7, 502-507.

BONVILLANI A., PEÑA F., GEA G., GÓMEZ G., PETRYNA A., PEREA J. (2010): Carcass characteristics of Criollo Cordobés kid goats under an extensive management system: Effects of gender and liveweight at slaughter. Meat Science, $86,651-659$.

CUTRIGNELLI M.I., TUDISCO R., BOVERA F., PICCOLO G., D'URSO S., INFASCELLI F. (2005): Influence of goat livestock systems on the performance of Cilentana kids. Proc. of 11th Seminar of the FAO-CIHEAM Sub-Network on sheep and goat production, Catania (Italy), September $8-10,41$.

DEVENDRA C. (2007): Perspectives on animal production systems in Asia. Livest. Sci., 106, 1-18

DUBEUF J.P., MORAND-FEHR P., RUBINO R. (2004): Situation, changes and future of goat industry around the world. Small Rumin. Res., 51, 165-173.

DUBEUF J.P., BOYAZOGLU J. (2009): An international panorama of goat selection and breeds. Livestock Science, 120, 225-231.

DOMINGO E., ABAD M., LANARI M.R., BIDINOST F. (2008): Características de las canales del caprino criollo del Neuquén. Archivos de Zootecnia, 57, 361364.

DASKIRAN I., KOR A., BINGOL M. (2006): Slaughter and carcass caracteristics of norduz male kids raised in either intensive or pasture conditions. Pak. J. Nutr., 5, 274-277.

FAJEMILEHIN SAMUEL O.K., SALAKO A.E. (2008): Body measurement characteristics of the West African Dwarf (WAD) Goat in deciduous forest zone of Southwestern Nigeria. Afr. J. of Biotech., 7, 14, 2521-2526.

GRUSZECKI T., SZYMANOWSKA A., LIPECKA CZ., PATKOWSKI K., JUNKUSZEW A. (1997): Dependency between some traits describing slaughter value of goat's carcass. Department of Sheep and Goat Breeding Agricultural University, Lublin, Poland (Report). 
KUNENE N.W., BEZUIDENHOUT C.C., NSAHLAIC I.V. (2009): Genetic and phenotypic diversity in Zulu sheep populations: Implications for exploitation and conservation. Small Rumin. Res., 84, 100-107.

MARICHAL A., CASTRO N., CAPOTE J., ZAMORANO M.J., ARGUELLO A. (2003): Effects of live weight at slaughter $(6,10$ and $25 \mathrm{~kg})$ on kid carcass and meat quality. Livest. Prod. Sci., 83, 247-256.

MEMIŠI N., ŽUJOVIĆ M., TOMIĆ Z., PETROVIĆ M.P. (2010): Influence of lactation order and live weight on milk yield and fertility traits in domestic balkan goat. Biotechnology in Animal Husbandry, 26, 179-185.

MEMIŠI N., BAUMAN F. (2007): Goat Nutrition. Admiralbooks. Belgrade, 230.

SHRESTHA J.N.B., FAHMY M.H. (2007): Breeding goats for meat production: a review 3. Selection and breeding strategies. Small Rumin. Res., 67, 113-125.

PEÑA F., PEREA J., GARCİA A., ACERO R. (2007): Effects of weight at slaughter and sex on the carcass characteristics of Florida suckling kids. Meat Science, 75, 3, 543-550.

SANTOS V.A.C., SILVA A.O., CARDOSO J.V.F., SILVESTRE A.J.D., SILVA S.R., MARTINS C., AZEVEDO J.M.T. (2007): Genotype and sex effects on carcass and meat quality of suckling kids protected by the PGI "Cabrito de Barroso". Meat Science, 75, 4, 725-736.

SAS Institute (2007): SAS software Version 9.1.3, SAS Institute Inc., Cary, NC, USA.

STANISZ M., ŚLÓSARZ P., GUT A. (2009): Slaughter value and meat quality of goat kids with various share of Boer blood. Anim. Sci. Pap. Rep. 27, 3, 189-197.

SHRESTRA J.N.B., FAHMY M.H. (2005): Breeding goats for meat production: a review. 1. Genetic resources, management and breed evaluation. Small Rumin. Res., 58, 93-106.

ŽUJOVIĆ M., TOMIĆ Z., PETROVIĆ M.P., MEKIĆ C., IVANOVIĆ S., NEŠIĆ Z. (2006): Development and perspective of goat production in Serbia. Biotechnology in Animal Husbandry, 22, 43-56.

ŽUJOVIĆ M., JOSIPOVIĆ S., TOMIĆ Z., STANIŠIĆ N., NEŠIĆ Z. (2008): Meat yield of kids of Serbian white breed depending on the body mass prior to slaughtering. Biotechnology in Animal Husbandry, 24, 61-69.

ŽUJOVIĆ M., STANIŠIĆ N., MEMIŠI N. (2009): Autochthonous Balkan goat breed - composition and traits of kid carcass. Biotechnology in Animal Husbandry, 25, 411-420.

YILMAZ A., EKIZ B., OZCAN M., KAPTAN C., HANOGLU H., YILDIRIR M. (2009): Effects of crossbreeding indigenous Hair Goat with Saanen on carcass measurements and meat quality of kids under an intensive production system. Animal Science Journal, 80, 460-467. 